Arbeidsliv, alkohol og kjønn - om arbeidsplassen som en mulig arena for forebygging av alkoholproblemer. Vi skjønner straks at det ikke dreier seg om en praktisk veileder, snarere en akademisk avhandling.

Det er nettopp det boken er. Og som forsker og akademiker spør jeg om hvorfor man utgir sin akademiske avhandling som bok tre år etter disputasen. Er det bare fordi det er viktig for universitetet i Stavanger å få dette gode forskningsarbeidet innlemmet i sin akademiske publikasjonsserie? Som leser, og ikke minst som bokanmelder, føler jeg meg snytt. Her er jo den akademiske diskursen for lengst avsluttet, disputasen fant sted 28. august 2007. Hvorfor ikke heller nå skrive slik at «vanlige folk» $i$ arbeidslivet kan ha nytte av boken?

For selv om boken er godt skrevet, på klingende nynorsk, er den så akademisk at avstanden til bakken blir for stor. Og vedleggene som det vises til i teksten (intervjuguider, informasjonsskriv etc.) har forsvunnet på veien.

Den empiriske delen av avhandlingen er basert på data fra forskningsintervju og narrativer fra personer som har opplevd at alkoholen etter hvert grep forstyrrende inn i tilværelsen, spesielt i forhold til jobben. Forskningsspørsmålet er: «Kva meiningsskapande prosessar involverer tilsette seg i når den enkelte i sin alkoholbruk blir eit tema på jobben?». Forfatteren viser, på en elegant måte, at det her ikke minst er klare kjønnsforskjeller: Mens mennenes alkoholrisiko særlig knytter seg til reisevirksomhet og det som kalles «relasjonsarbeid i fjerne relasjonar», finnes kvinnenes risikosituasjoner i det som kalles «omsorgsarbeid i nære relasjoner». Sagvaag skriver finurlig at for mennene blir arbeidsarenaen en arena for relasjoner, og for kvinnene blir hjemmearenaen en arena for arbeid.

Det er mulig jeg ikke helt forstår den samfunnsvitenskapelige plattformen denne studien er basert på. Men forfatteren gjør det ikke lettere for meg når hun skriver om naturvitenskap og menneskekunnskap (s. 25): «Når det gjeld fenomen som er ontologisk subjektive i sin natur, som til dømes opplevingar og erfaringar, er teleologiske forklaringar og hermeneutisk forståing, relevant.» Her er det mange kvalitative honnørord. Men jeg stusser over hvordan en studie som denne kan gjennomføres uten i særlig grad å diskutere opplevelsen av alkoholavhengighet som et biologisk fenomen. Videre savner jeg en bredere forståelse av kulturelle forskjeller i alkoholtilgjengelighet - drikkekulturenes «fuktighet». Selv om Sagvaag viser at det kan være betydelige forskjeller i oppfatningen av hva som er avvikende alkoholatferd, synes jeg ikke dette utnyttes godt nok ved f.eks. å se på klassiske yrkesmessige forskjeller i forhold til fuktighet, altså yrkesmessig variasjon i alkoholrisiko. Men det utkrystalliseres ett klart, ikke-akade- misk råd, særlig til mannlige alkoholrisikanter: Reis mindre! Dette har allerede vært fremme i media en rekke ganger med utgangspunkt i Sagvaags forskningsarbeid.

Olaf Gjerløw Aasland

Legeforeningens forskningsinstitutt

\section{En advarsel mot psykologprofesjonen}

Ole Jacob Madsen

Den terapeutiske kultur

205 s. Oslo: Universitetsforlaget, 2010. Pris NOK 319

ISBN 978-82-15-01509-5



Psykologprofesjonen har ekspandert enormt. Ifølge forfatteren som er psykolog og filosof, har den utkonkurrert psykiatrien, og psykologisk forståelse gjennomsyrer mer og mer vårt samfunn. Den passer som hånd $\mathrm{i}$ hanske med nyliberalismens og individualiseringens prosjekt hvor målet er at den enkelte borger kontrollerer seg selv og tilskriver alle feil til seg selv og ikke til samfunnet eller politikerne. Hvis det ikke går så godt som ønsket, har det sin rot i den enkeltes mangel på selvfølelse eller forstyrrelser i «det mentale». Da trenger man hjelp av eksperter. Og psykologene stiller opp i selvhjelpslitteraturen, i psykiatrien, i skolen, i kommunen, $\mathrm{i}$ idretten, $\mathrm{i}$ bedriftene, $\mathrm{i}$ såpeseriene osv. Som en motvekt til denne suksessfortellingen, har boken ett eneste budskap: «Uansett hvor velmenende psykologers interesser i å forske på psyken og bistå enkeltmennesker i det individualiserte samfunn er, er resultatet at denne virksomheten svekker den samfunnsmessige forestillingsevnen, som er en forutsetning for at individer er kapable til å forstå hvordan egen skjebne henger sammen med samfunnsendringer og tusener andres skjebner. Og verst av alt: Dermed undergraves også individenes vilje til forandring av sin situasjon (status quo) utover å bli (litt) bedre utgaver av seg selv.» Forfatteren advarer mot at stadig flere ikke-psykologiske fenomener blir forstått som noe som oppstår i enkeltmenneskers hjerne. Psykologene bør heve blikket og også se hvilken sosial og politisk situasjon pasientene er i.

Boken er velskrevet, men temmelig ensidig til tross for forsøk på å la motforestillinger komme til orde. Det eneste budskapet gjentas og gjentas, men gjentakel- sene er til å holde ut. Den er skrevet ut fra et filosofisk perspektiv og refererer en del sentrale kritikere av individualiseringen, nyliberalismen og psykologprofesjonen. Men forfatteren nevner ikke den psykologifobien som tvert imot preger mye av sosiologi, litteraturvitenskap, statsvitenskap og idéhistorie, og som hindrer inkludering av kunnskap om f.eks. personlighet, utviklingspsykologi, gruppedynamikk, sosialpsykologi og det ubevisste i sin forståelse av fenomenene.

Madsen har også noe å si til psykiatrien som kan gi støtte til individualiseringen i samfunnet gjennom å forsterke sitt biologiske perspektiv. Hvis årsaken til psykiatriske lidelser blir oppfattet ensidig som «feil» i hjernen, «slipper man» å påvirke pasientens eventuelt utålelige livssituasjon eller stimulere til å gjøre opprør mot den. Men i så fall forlater man den biopsykososiale modellen.

Forfatteren understreker at den individorienterte psykologien er nødvendig og nyttig, men advarer samtidig mot at man er med på å konservere pasientproduserende krefter i samfunnet. Hvis du trenger argumenter for å løfte blikket og fokusere på pasientenes livssituasjon, er dette boken for deg. Det er den også for alle som er interessert i forholdet mellom psykiatri/psykologi og samfunn/politikk.

\section{Per Vaglum}

Avdeling for medisinske atferdsfag Institutt for medisinske basalfag

Universitetet i Oslo

\section{Lite nytt om kroniske sykdommer}

Reinhard Busse, Miriam Blümel,

David Scheller-Kreinsen et al.

Tackling chronic disease in Europe

Strategies, interventions and challenges.

111 s, ill. København: WHO, 2010. Pris CHF 30 ISBN 978-92-890-4192-8

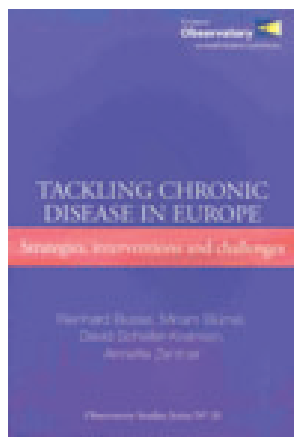

Forfatterne er knyttet til Department of Health Care Management ved Berlins teknologiske universitet. Vi får ikke vite deres bakgrunn, men det virker ikke som leger er blant forfatterne. Det er litt uklart hvem mål-

gruppen er, men man har vel tenkt på helsebyråkrater og politikere med tilknytning til helsevesenet.

Frem til siste verdenskrig var det infek- 
sjonssykdommer, bl.a. tuberkulose, som dominerte sykdomsbildet i Europa, og ikke minst ble barn og unge rammet. Etter krigen har hjerte- og karsykdom, kreft og psykiske lidelser overtatt, og særlig har middelaldrende og eldre vært utsatt. I dag er mange med hjerte- og karsykdom, diabetes, astma, obstruktive lungesykdommer og visse typer av kreft, hiv/aidssykdommer og noen psykiske lidelser, som schizofreni og demens, å betrakte som kroniske pasienter, og de står for mesteparten av sykdomsbyrden og dødeligheten i Europa.

WHO definerer kronisk sykdom som sykdom med lang varighet og vanligvis langsom progrediering - uten at verken tidsaspektet eller progredieringen er definert. I 2002 var kroniske sykdommer ifølge forfatterne årsak til om lag $86 \%$ av dødsfall i Europa. Bare $7 \%$ skyldtes infeksjonsog ernæringssykdommer og $6 \%$ ulykker. Mange kroniske sykdommer er knyttet til høyere alder, men en livsstil med stort tobakks- og alkoholforbruk, risikobetinget seksuell atferd, overvekt og inaktivitet spiller også en sentral rolle.

I denne kortfattede boken omtaler bidragsyterne, til dels ved tabeller, den byrden som kroniske lidelser skaper for samfunnet, både for den enkelte og for økonomien. Deretter omtaler man de strategiene man kan ta i bruk for å takle kronisk sykdom, og endelig diskuterer man de utfordringene man står overfor.

Røyking er fortsatt en viktig årsak til sykdom og død i Europa. Andelen røykere er nå på omkring $30 \%$, men i Øst-Europa, ikke minst i de baltiske landene, har antall røykere økt de siste årene, særlig blant kvinner og yngre. Flere land har redusert sitt totale alkoholkonsum, bl.a. Frankrike, men fortsatt ligger Øst-Europa etter. En tredel av den europeiske befolkningen regnes for overvektige. Svært betenkelig er det at overvekt øker blant barn.

Forfatterne mener at dødeligheten av diabetes og obstruktiv lungelidelse vil stige. Den sykdommen som vil øke mest, er demens - fordi det blir flere eldre i samfunnet. Andelen over 65 år vil øke fra $15 \%$ i 2000 til over $23 \%$ i 2030 . Andelen over 80 år vil bli mer enn fordoblet i samme periode.

Utgifter til behandling og omsorg for kronisk syke går opp og tar en økende del av de nasjonale budsjettene. De fleste landene forsøker med forebygging og tidlig diagnostisering. Forskning viser at man oppnår best resultat når man kombinerer forskjellige tilnærminger. I en del land, ikke minst i Storbritannia, har man utviklet nye profesjoner som «nurse practitioners» og «community nurses», som både driver klinikker, og som besøker pasienten hjemme, åpenbart med godt resultat.

Forfatterne går inn for å stimulere utviklingen av nye medikamenter. De har da også fått støtte av Pfizer til den forskningen som denne boken bygger på. De foreslår også økonomisk premiering, bedre organisering av helsevesenet og større bruk av informasjonsteknologi, forslag vi har hørt mange ganger før. Jeg tror ikke mange vil bli stimulert av denne oversikten. Nye tanker er det lite av.

\section{Einar Kringlen}

Psykiatrisk institutt

Universitetet i Oslo

\section{Imponerende om røykeavvenning}

Keir E Lewis, red.

Smoking cessation

164 s, tab, ill. Oxford: Oxford University Press, 2010. Pris GBP 6

ISBN 978-0-19-955625-0

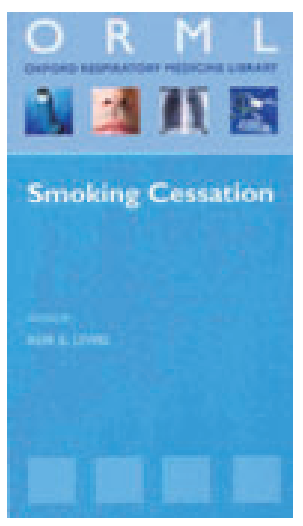

Dette er en kortfattet bok om røykeavvenning hvor bidragsyterne har som mål å levere en kompakt, praktisk og kunnskapsbasert veiledning og gi gode råd i dagligdagse, kliniske situasjoner. Målgruppen er leger og sykepleiere som behandler røykere, samt personer med ansvar for medisinsk og annen helsefaglig utdanning

Boken består av 15 kapitler med følgende temaer: røykingens epidemiologi/ historie $\mathrm{i}$ et verdensperspektiv, fysiologiske og psykiske effekter av røyking, metoder for røykeavvenning og farmakologiske og ikke-farmakologiske hjelpemidler. Så følger åtte kapitler om hvilke motivasjonsfaktorer som er særlig viktige, og hvilke medikamenter som, ifølge litteraturen, er effektive ved kols (kronisk obstruktiv lungesykdom), koronarsykdom, planlagt kirurgi, graviditet, kreft, psykisk sykdom samt for unge røykere og jenter/kvinner. I tillegg omtaler forfatterne $\mathrm{i}$ egne kapitler diverse andre medisinske tilstander og fremtidens farmakologi. Her diskuterer de også forhold som kols og depresjon, røyking og sårtilheling, viktigheten av røykestopp minst åtte uker før planlagt kirurgi og røyking og osteoporose.

Kapitlene begynner med oppsummerte hovedpunkter og har boksdiagrammer med punktvise oppsummeringer som bidrar til god oversikt over temaene. Avslutningsvis diskuterer forfatterne kasuistikker, viser praktiske konsultasjonsark og flytdiagrammer til bruk i røykeavvenning, kommer med forslag til tilnærming overfor høyrisikogrupper og henviser til aktuelle nettsider De viser også flere praktiske eksempler på hvordan man skal henvende seg til politikere og helsemyndigheter for å foreslå røykeforebyggende tiltak. Boken er redigert av lungelege og indremedisiner Keir Lewis og skrevet av til sammen 12 forfattere, de fleste av dem unge og engelske, med åpenbar klinisk erfaring.

Dette er en imponerende kraftpakke om røykeavvenning; lettlest, komprimert, oversiktlig, praktisk og på alle måter klinisk.

Det er flere viktige kliniske presiseringer av ren praktisk karakter, som det rett og slett er flott å se på trykk, f.eks. at en lege som vil henvise en pasient til en spesialist i røykeavvenning, ikke bare skal anmode pasienten om å gjøre det selv, men faktisk bør gjøre det for pasienten. Videre er det et klart søkelys på hvor viktig det er med oppfølgingssamtaler etter røykestopp.

Forfatterne fremhever ofte de gylne øyeblikkene som kan øke motivasjonen og mestringen, og som mange helsearbeidere bør være oppmerksomme på i sitt kliniske arbeid. Disse poengteringene er nyttig informasjon for de fleste og bør bidra til å øke årvåkenheten hos helsearbeidere som snakker med røykere. Især gir de i kapitlet om røyking og kreft flere overbevisende grunner til økt røykeavvenningsinnsats i denne gruppen.

En rett og slett imponerende liten bok om et svært viktig tema - som jeg er glad for å ha lest.

\section{Frode Gallefoss}

Seksjon for lungesykdommer

Sørlandet sykehus

Kristiansand

\section{Flatpakke eller puslespill?}

Steve lliffe

From general practice to primary health care The industrialisation of family medicine. $233 \mathrm{~s}$, tab, ill. London: Oxford University Press, 2010. Pris USD 55 ISBN 978-0-19-921450-1

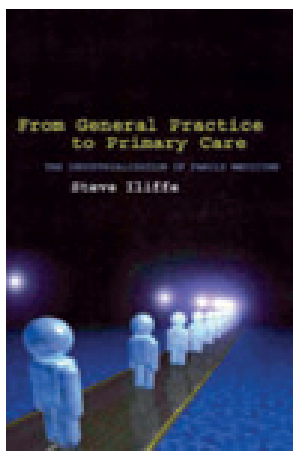

Allmennlegens møte med sine pasienter er prototypen på legepasient-forholdet. Et vellykket møte er avhengig av at pasienten har tillit til legen, og at legen forstår hvorfor pasienten har søkt kontakt. Helst bør legen kjenne pasienten godt fra før og vite «alt» om pasientens liv og familie. Det dreier seg med 